\title{
Evaluation of Continuous System for Recovery of Volatiles from Roasted Coffee and its Effects on Soluble Coffee Products
}

\author{
Naoto Imura* and Osamu Matsuda* \\ *Ajinomoto General Foods, Inc. Central Research Laboratories, \\ 6410 Minamitamagaki-cho, Suzuka-shi, Mie 513
}

\begin{abstract}
Volatile aroma compounds and acids were recovered in a short time period from roasted and ground coffee by steaming in a continuous counter-current apparatus. It was found that the recovery of volatiles depended upon the temperature of coffee steamed rather than the residence time of the coffee in the equipment. The total acid recovered both in the aroma condensate and in the aqueous extract from the steamed coffee with 5 minutes residence time was almost the same as that in a non-steamed coffee control. The generation of excess acids during steaming could therefore be minimized by short steaming times, compared with the traditional method of steaming a static coffee bed in a percolation column.

As steam flow rate was increased to obtain more condensate, the amount of total organic volatile compounds recovered in the condensate did not increase proportionally. Recovery of sulfur-containing compounds, however, significantly increased with the increase of steam flow rate.

Organoleptic evaluation of the coffee to which steam aroma was added suggested that sulfur-containing compounds were a key facter in obtaining regular brewed coffee flavor in a cup of soluble coffee.

The flavor of the steamed coffee deteriorated rapidly upon discharge from the equipment to the atmosphere. By organoleptic evaluation, a significant deteriorated note was perceived in the extract prepared from steamed coffee after 30 minutes hold-up. Acid generation in the steamed coffee increased rapidly after 90 minutes hold-up.
\end{abstract}

More than 50 years have passed since a spray-dried coffee product was first commercially produced in the United States ${ }^{1)}$. Since that time, significant effort in developing soluble coffee has been focused on improving its flavor. An ideal soluble coffee is one which has the same flavor as regular brewed coffee.

One of the processes known in the art for increasing roasted and ground flavor in a soluble coffee product is steaming the fresh coffee prior to water extraction ${ }^{2)-4)}$. The condensate of the steaming process ("steam aroma") contains many desirable aroma and flavor compounds which are essential for 'fresh brewed flavor', but are difficult to extract with limited amounts of water due to their high solubility in coffee oil. The steaming technique allows for higher recoveries of these aromas. Additionally, the recovery of aromas via steaming protects the aromas from excessive thermal treatment and loss during the water extraction and the thermal concentration of the extract which follow in the soluble coffee process. The steam aroma is returned to the coffee extract just prior to drying, thereby minimizing degradation.

The process has the advantage of imparting more fresh coffee flavor to the soluble coffee product. However the process results in soluble coffee products which are more sour and acidic than non-steamed controls. The increase in sourness appears to be due to the generation of acids during the steaming process ${ }^{2}$. Therefore the objective of this work was to establish if 
the sourness could be reduced by changing the steaming conditions or process.

A device is described in U.S. patent ${ }^{5)}$ to recover volatiles of coffee with steam in a continuous manner. The patent claims that steam aroma can be recovered in a shorter period of time as compared with conventional methods; i.e., where steam is applied to roasted and ground coffee in the same vertical column as soluble solids of coffee are extracted. We designed a device to recover steam aroma in a continuos manner with the same principles as the patent.

Our objectives were to evaluate the characteristics of a continuous system in recovering volatile aromas from coffee grounds and in reducing acid generation during steaming. Detrimental effects of steaming on the base coffee such as flavor deterioration were also examined.

\section{Materials and Methods}

\section{Equipment}

The detail of the equipment is illustrated in Fig. 1. The main vessel is made of stainless steel and is $2000 \mathrm{~mm}$ in length (between inlet and outlet rotary lock) and $125 \mathrm{~mm}$ ID. The roasted and ground coffee was fed by a constant volumetric feeder to the steaming vessel through a rotary lock. The vessel is equipped with a screw wich is driven by a variable speed motor. The screw pitch is $100 \mathrm{~mm}$ and the

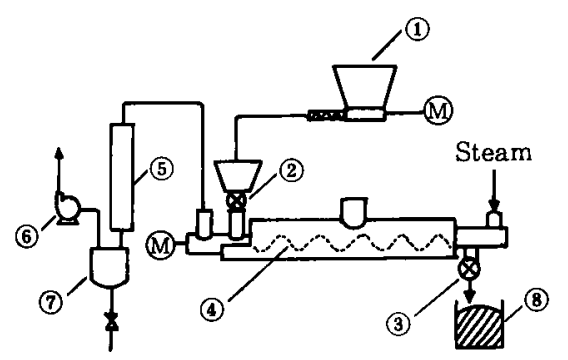

Fig. 1 Equipment for continuous recovery of coffee volatiles

(1), Coffee feeder ; (2), (3), Rotary valve ;

(4), Screw ; $\quad$ (5), Condenser ;

(6), Blower; (7), Condensate tank ;

(8), Residual coffee shaft diameter is $40 \mathrm{~mm}$. Steam can be fed either in co-current or counter-current manner. Steam leaving the devices which contains coffee volatiles was condensed with a condenser at $5^{\circ} \mathrm{C}$ to recover the steam aroma. The system was maintained under a slight vacuum with a blower.

The amount of the condensate recovered is designated by the "Draw Off Factor" (DOF) which represents the ratio of weights of condensate collected to the coffee fed over the same period of time. For our experiments, coffee flow rates of 16 to $48 \mathrm{~kg} / \mathrm{h}$ and steam flow rates of 5 to $28 \mathrm{~kg} / \mathrm{h}$ were employed.

Materials (coffee beans)

Roasted Colombian coffee beans, roasted to a $20^{\circ} \mathrm{L}$ value, were ground by a grinder to a $3000 \mu \mathrm{m}$ mean particle size.

Gas chromatographic analysis

The steam condensate recovered from the equipment was directly injected into a Hewlett Packard HP-5840 gas chromatograph (GC) which was equipped with a 12 feet $\times 3 \mathrm{~mm}$ I.D. packed column (10\% SP-1000 on Chromosorb $\mathrm{W}-\mathrm{AW}$ ) and a Flame Ionization Detector (FID). The initial temperature was $70^{\circ} \mathrm{C}$, the ramp rate was $8^{\circ} \mathrm{C} / \mathrm{min}$ and the final temperature was $180^{\circ} \mathrm{C}$ for $10 \mathrm{~min}$. The injection size was $2 \mu l$.

The peaks on the chromatogram were arbitrarily divided into three regions, "Lights", "Mediums" and "Heavies". "Lights" starts from the beginning of the chromatogram through 2,3-pentandione (Retention time : 4.3 min). The compounds in this region are primarily low molecular weight ketones and aldehydes which are presumably heat-sensitive. The "Heavies" region starts from the furfural peak (retention time: $10.8 \mathrm{~min}$ ) through the end the chromatogram. "Mediums" is the intermediate region between "Light" and "Heavies".

Sulfur-containing compounds in the condensate were analyzed using a Hewlett Packard HP-5840 gas chromatograph equipped with a Flame Photometric Detector (FPD) and a 6 feet $\times 2 \mathrm{~mm}$ I.D. packed column (10\% SP-1000 on Chromosorb W-HP). Two $\mu l$ aroma con- 
densate was directly injected on to the column. The initial temperature was $70^{\circ} \mathrm{C}$, the ramp rate was $8^{\circ} \mathrm{C} / \mathrm{min}$ and the final temperature was $170^{\circ} \mathrm{C}$ for $10 \mathrm{~min}$.

The analytical results by $\mathrm{GC}$ are presented as FID counts per gram of roasted and ground $(R \& G)$ coffee (dry basis)for total organic compounds, and in ng 2,4-dimethylthiazol per gram $R \& G$ coffee (dry basis) for sulfur-containing compounds.

The aqueous extracts of steamed coffee were also analyzed by gas chromatoraphy. The extract was diluted with water to a $1.0 \%$ soluble solids concentration and applied to a Hewlett Packard "Purge and Trap" system. The extract is placed in a glass tube and is purged with nitrogen gas. The volatiles are trapped on a Tenax adsorbent. The volatiles concentrated on the adsorbent are then desorbed and directed to the same column as that for the total organic compounds analysis. The results are decribed in FID counts per gram soluble coffee solids.

\section{Acid titration}

Acids in the condensate were titraed with 0.1 $\mathrm{N}$ sodium hydroxide solution to an endpoint of $\mathrm{pH}$ 8.1. The results are described in $\mathrm{m}$ (milli) equivalent per gram dried coffee. The acid content of freezse-dried coffee was determined on $100 \mathrm{ml}$ of a $1.5 \%$ soluble solids solution by titration to the same endpoint. The acid content of the roasted coffee was measured by placing 10 grams of steamed coffee or nonsteamed coffee in $200 \mathrm{ml}$ of water at $25^{\circ} \mathrm{C}$ and allowing $16 \mathrm{~h}$ for extraction of soluble solids. Hundred $\mathrm{m} l$ of the extract was titrated as above.

\section{Moisture content}

Moisture content in the coffee was measured by an oven drying method $\left(105^{\circ} \mathrm{C}, 16 \mathrm{~h}\right)$.

Organoleptic evaluation

The extract from the steamed coffee was evaluated by five trained expert panelists.

\section{Results and Discussion}

1. Gas Chromatographic Analysis of Steam Condensate

Figure 2 shows a typical chromatogram of

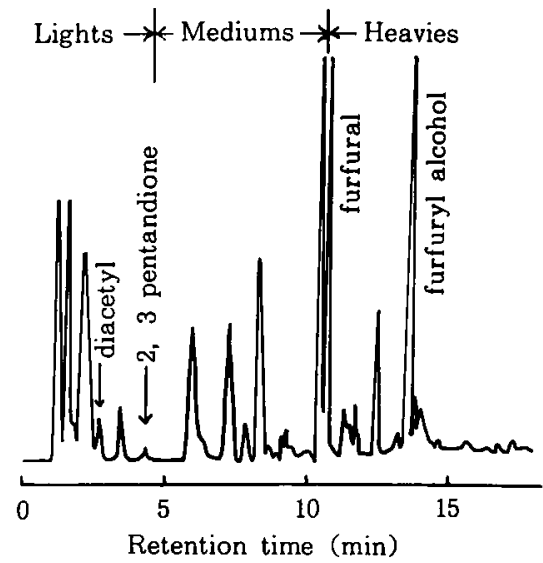

Fig. 2 Typical gas chromatogram (FID) of steam condensate

the steam condensate. In the "Lights" region, acetaldehyde, diacetyl and 2, 3 pentandione, which have relatively high volatility, are obrserved. On the other hand, furfural and furfuryl alcohol, which have lower volatility, are observed in the "Heavies" region.

\section{Effects of Direction of Steam Flow}

Steam was fed to the system either co-currently or counter-currently to the coffee by using the manifolds on the system.

As Table 1 shows, the direction of steam flow significantly affected the recoveries of acids and volatiles. The amount of volatiles recovered in the steam condensate under counter-current steaming was almost twice as much as that under co-current steaming. The proportion of "Lights", "Mediums" and "Heavies" in the chromatograms of steam aroma obtained with counter-current steaming was close to that with co-current. Acids recovered in the condensate showed the same tendency as volatile aromas in that more acids were recovered with counter-current than cocurrent steaming.

When steam was applied counter-currently, it tended to push the coffee back to the feed section of the system along the screw flight, since the directions of these flows are opposite to each other. This resulted in having the coffee more tightly packed in the vessel, reducing the void space in the coffee bed, and 
Table 1 Volatiles and acids recovery under co- and counter-current steaming conditions with different residence time of coffee

\begin{tabular}{lcccc}
\hline \hline & \multicolumn{4}{c}{ Flow direction } \\
\cline { 2 - 5 } & \multicolumn{2}{c}{ Co-current } & \multicolumn{2}{c}{ Counter-current } \\
\hline Residence time (min) & 5 & 15 & 5 & 15 \\
$\begin{array}{l}\text { Draw Off Factor (-) } \\
\text { Volatiles }\end{array}$ & 0.32 & 0.30 & 0.31 & 0.29 \\
$\quad\left(\times 10^{6}\right.$ counts/g coffee) & & & & \\
$\quad$ Lights & 47 & 32 & 80 & 60 \\
$\quad$ Mediums & 262 & 235 & 550 & 382 \\
$\quad$ Heavies & 206 & 194 & 457 & 417 \\
$\quad$ Total & 515 & 461 & 1087 & 859 \\
Acids & 0.0211 & 0.0195 & 0.0448 & 0.0278 \\
$\quad$ (m equivalent/g coffee db) & 11 & 11 & 14 & 17 \\
Moisture $(\%)$ & 66 & 45 & 74 & 33 \\
Temperature increase & & & & \\
$\quad$ of coffee $\left({ }^{\circ} \mathrm{C}\right)$ & 3 & 9 & 5 & 7 \\
Temperature drop & 300 & 200 & 2100 & 230 \\
$\quad$ of steam $\left({ }^{\circ} \mathrm{C}\right)$ & & & & \\
Pressure difference $\left(\mathrm{mm} \mathrm{H}_{2} \mathrm{O}\right)$ & &
\end{tabular}

improving the coffee/steam contact. This might be a reason for the higher recoveries of volatiles and acids under counter-current operation. As shown in Table 1, the pressure difference across the system and moisture content of the steamed coffee also suggest this phenomena. Under counter-current steaming, a relatively larger pressure difference was observed than under co-current. The temperature of the steamed coffee rose higher under counter-current than co-current operation with the same residence time of the coffee in the vessel. This higher temperature operation would also lead to the difference in aroma and acid recoveries. The water content of the counter-currently steamed coffee was also higher than that of the co-current one.

\section{Effects of Residence Time}

As described before, counter-current steaming enables the recovery of almost twice as much volatiles as co-current. The effects of residence time on the recovery of volatiles were also investigated.

It is difficult to calculate residence time from the screw revolution and its pitch, since there is significant axial back mixing of the coffee grounds. Thus, several unground roasted coffee beans were fed to the system and the time for them to be discharged was measured as the residence time.

As shown in Table 1, the amount of volatiles recovered in the condensate with shorter residence time ( $5 \mathrm{~min}$ ) was slightly larger than that with longer residence time $(15 \mathrm{~min})$ for both co- and counter-current conditions. The proportions of "Lights", "Mediums" and "Heavies" in the chromatograms for co- and counter-current steaming were not significantly diff ferent from each other. The acids recovered in the condensate showed the same tendency as the volatiles.

The lower steam flow rate with longer residence time $(15 \mathrm{~min})$ resulted in the larger temperature drop of steam across the system for both directions of steam. Accordingly, the temperature of the steamed coffee discharged with longer residence time did not increase as much as that with shorter residence time. The lower recoveries of volatiles and acids with longer residence time were caused by the lower 
temperature of the coffee. This suggests that the acids and volatiles in the coffee diff use into the steam in a short period of time and that recoveries are governed more by temperature than time.

\section{Effects of Increase of Draw Off Factor on Volatile Recovery}

Figure 3 shows changes in volatile recovery (total organic compounds and sulfur-containing compounds) and outlet steam temperature as DOF increased. The recovery of total organic compounds showed a plateau at 0.6 DOF. On the other hand, the recovery of sulfur-containing compounds rapidly increased beyond DOF 0.6. The outlet steam temperature increased as the DOF increased. The recovery of sulfur-containing compounds appears correlated to the outlet steam tempera-

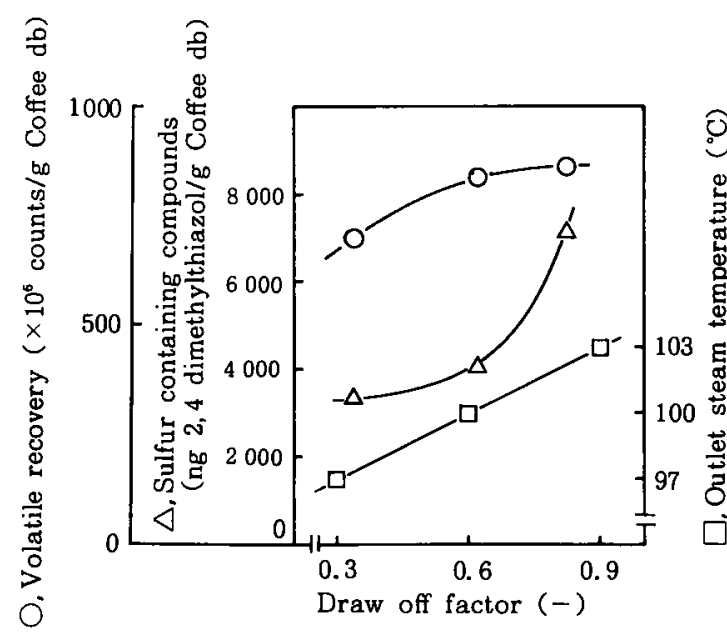

Fig. 3 Recoveries of total volatiles and sulfur-containing compounds and outlet steam temperature with large DOF ture. Organoleptic evaluation indicated that freeze-dried coffee sample, to which the steam condensate of 0.9 DOF was added, showed a stronger intensity of a "Floral" note that is typically perceived in a freshly brewed Colombian coffee than the samples with lower DOF condensates. This suggests that recovery of sulfur-containing compounds could be an index of regular brewed coffee-like flavor in soluble coffee products. This is consistent with the work of NoOMEN ${ }^{6)}$ who describes the importance of sulfur-containing compounds to coffee flavor. A more detailed analysis of sulfur-containing compounds would be needed to determine which components have the greatest affect upon reproducing regular brewed coffee flavors on a soluble coffee.

\section{Excess Acid Generation}

IMURA and MATSUDA reported that steaming of a static coffee bed in a column generated an excess amount of acids because the coffee was exposed to high temperature ${ }^{2)}$. The residual steamed coffee from the continuous system was extracted with water to discover if any acids were generated during steaming. As shown in Table 2, the total amount of acids both in the steam aroma and in the extract obtained from the steamed coffee (with 5 min residence time) is almost the same as that in the extract from the non-steamed coffee. The generation of excess acids was therefore minimized in the continuous counter-current system with the short residence time. In the organoleptic evaluation of freeze-dried coffee samples which had steam aroma added back, the same intensity of sourness was perceived in the cup with steam aroma of $5 \mathrm{~min}$ residence time, as in the freeze-dried sample from a non-steamed coffee control.

Table 2 Generation of excess acids by steaming in the continuous system (milli equivalent/g coffee $\mathrm{db}$ )

\begin{tabular}{ccccc}
\hline \hline $\begin{array}{c}\text { Acids in } \\
\text { steam aroma }\end{array}$ & $\begin{array}{c}\text { Acids in } \\
\text { residual } \\
\text { coffee }\end{array}$ & $\begin{array}{c}\mathrm{A}+\mathrm{B} \\
\text { Total } \\
\text { acids }\end{array}$ & $\begin{array}{c}\mathrm{C} \\
\text { Acids in } \\
\text { non-treated } \\
\text { coffee }\end{array}$ & $\begin{array}{c}(\mathrm{A}+\mathrm{B})-\mathrm{C} \\
\text { Excess acids } \\
\text { generated by } \\
\text { steam }\end{array}$ \\
\hline 0.0414 & 0.136 & 0.177 & 0.179 & -0.002 \\
\hline
\end{tabular}

Steaming condition : 5 min residence time, 0.31 DOF 


\section{Steamed Coffee Deterioration}

It is possible that the steamed coffee may deteriorate while it is exposed to the atmosphere until loading into a percolator for extraction since the temperature of the discharged coffee is as high as $100^{\circ} \mathrm{C}$ with counter-current steaming. The deterioration may be dependent upon the time the steamed coffee is held. Undesirable effects on flavor and sourness of the coff ee extract may therefore be caused.

As shown in Fig. 4, the $\mathrm{pH}$ of the extract from the steamed coffee decreased and the amount of acids rapidly increased 90 min after the coffee was discharged. Volatile compounds in the "Mediums" and "Heavies" regions (measured by gas-chromatography) tended to increase slightly. Some amino carbonyl reactions may take place which can generate compounds having low volatilities such as furfural and pyrazines ${ }^{7)}$. On the other hand, those aromas in the "Lights" region were rapidly lost after discharge, as shown in Fig. 5. These components, which have rather high volatilities, may be vaporized or decomposed while the steamed coffee is being held, although the compounds having relatively high volatilities such as aldehydes may be additionally generated via amino carbonyl reactions.

The mechanisms of generation of acids during steaming of coffee and storage of steamed coffee are still not fully understood. However, it is possible that aldehyes, which are not only major volatile components of coffee

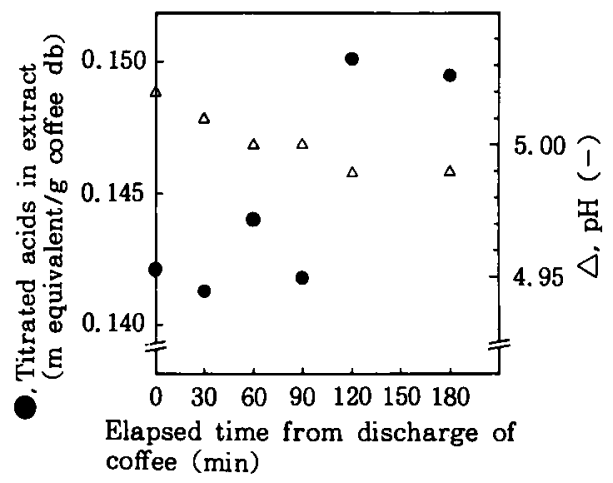

Fig. 4 Change of acids in residual coffee during storage

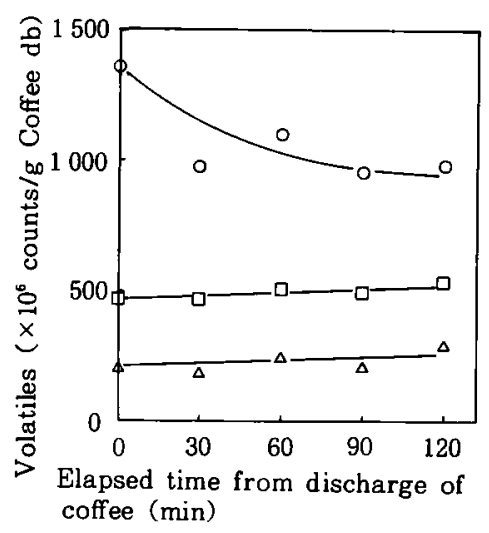

Fig. 5 Change of volatiles in residual coffee during storage

$\bigcirc$, Lights ; $\triangle$, Mediums ; $\square$, Heavies

but also generated via amino carbonyl reactions, may be oxidized to form carboxylic acids ${ }^{11}$.

The steamed coffee was extracted with hot water $\left(85^{\circ} \mathrm{C}\right)$ in a bench top glass column to evaluate its organoleptic characteristics. The extracts from the steamed coffee which were held in the atmosphere for more than $30 \mathrm{~min}$ exhibited a note of deterioration, called "Cooked", which is ordinarily perceived in brewed coffee heated for a long time. The compound or compounds which gives this note has not been identified yet. Aromas generated via amino carbonyl reactions as described above may relate to the note.

Acknowledgments: We are grateful to Professor T. Yano, Tokyo University, for reviewing the manuscript and providing helpful advice to us. We also wish to thank Mr. E. TureK of Kraft General Foods, Banbury, U.K. for his kind advice and considerable assistance in editing English expressions.

\section{References}

1) Sivetz, M. and Desrosizr, N. W. : Coffee Technology, (AVI Pub., Connecticut), p. 317 (1979).

2) Imura, N. and Matsuda, O.: Nippon Shokuhin Kogyo Gakkaishi, 39, p531 (1992)

3) General Foods: U.S. Patent, No. 3, 132, 947 (1963). 
4) General Foods: U.S. Patent, No. 3, 615, 665 (1967).

5) General Foods: U.S. Patent, No. 3, 244, 352 (1966)

6) Noomen, P.J.: Chem. Mikrobiol. Technol. Lebensm. 6, p. 48 (1979)

7) Baltes, W.: J. Food Chemistry, 9, p. 59 (1982)

(Received Sep. 26. 1991)

連続式スチーミング装置による婄煎コーヒーからの

香気成分の回収とそのインスタントコーヒー 等品への影䈏

井村直人 * 松田 修*

“味の素ゼネラルフーヅ(株)研究所

（訳13 三重県鈴鹿市南玉垣町 6410）

連続式のスクリューコンベアタイプの装置においてコ
一七ーの流れと向流的に水蒸気を供給することによって， 焙煎し粉砕したコーヒーから揮発性の香気成分や酸を短 時間に回収することができだ，揮発性成分の回収は，コ ーヒ一の系内滞留時間よりもコーヒーの温度に依存した。 得られる水蒸気疑縮水に含まれる酸の総量上，処理後の コーヒー中に含まれる酸の総量の和は，滞留時間が 5 分 の場合，末処理の物とほぼ同等であり，水蒸気处理によ る酸の生成はほほ抑制された．水蒸気の流量を増加させ， 多くの凝縮水を得ると，硫黄化合物の回収量が著しく增 加し，この龊縮水を添加したコーヒーは官能的に通常の レギュラーコーヒーに近いと評価された，この硫黄化合 物がレギュラーコーヒーのフレーバーをインスタントコ 一ヒーに再現するための重要なファクターであると考え られる. 水蒸気処理コーヒ一の官能的な劣化は 30 分を 経過すると明らかに認められ，その酸の量も 90 分後加 ら顕著に增加した。 